\title{
THE SPECIALTIES OF THE PHARMACEUTICAL VALUE CHAINS IN HUNGARY
}

\author{
Katalin ANTALÓCZY - Tamás GÁSPÁR - Magdolna SASS
}

(Received: 28 May 2019; revision received: 21 October 2019;

accepted: 6 November 2019)

\begin{abstract}
The length, the composition, the quality and the characteristics of value chains essentially determine the corporate as well as the macroeconomic performance of the economic sectors and industries. Hungary has a strong tradition in the pharmaceutical industry but its dynamising impact seems to be limited on the economy. The aim of this paper is to detect and reveal the specialties of the Hungarian pharmaceutical industry both in space and time by a value chain analysis. Our method is partly quantitative, we use an input-output analysis; and partly qualitative, relying on interviews with the representatives of pharmaceutical companies. We found that the Hungarian pharma value chain is really special, having relatively short backward and forward linkages with mainly indirect value-added contribution as well as high import content of exports. However, our company interviews revealed the fundamental differences between original and generic value chains - i.e. again a pharma industry-specific distinction. Having relatively little original and more substantial generic production in Hungary explains much of the value chain specialties, which leaves its mark on the limited impact of the industry on the national economy.
\end{abstract}

Keywords: pharmaceutical industry, global value chains, Hungary

JEL classification indices: L65, C67, F23

Katalin Antalóczy, Professor at the Foreign Trade Department of the Budapest Business School. E-mail: Antaloczy. Katalin@uni-bge.hu

Tamás Gáspár, Researcher at the Foreign Trade Department of the Budapest Business School. E-mail: Gaspar.Tamas@uni-bge.hu

Magdolna Sass, corresponding author. Researcher at the Budapest Business School and Centre for Economic and Regional Studies, Budapest, Hungary. E-mail: Sass.Magdolna@krtk.mta.hu 


\section{INTRODUCTION}

The macroeconomic structure of a country and its strategic management are facing several challenges. The new technological era is changing the value-added capabilities, the efficiency and the relative importance of industries, since to a different extent it influences the research and development (R\&D) content of the industries, the level how each production process can be automatized or how the sales structure shrinks. At the same time, besides the speeding up of reproduction processes, the interfering crises enhance instability and, as a consequence, the capability to monitor the spillover effects. Hence, even if the pure structure of the economic sectors does not change, their value creating power, its shift among the production phases as well as the performance of the industries in time do change. The efficiency of the economic policy and strategy will crash on a standard structural evaluation basis unless it understands the nature of value chains and their specialities by industries.

The length, the composition, the quality and the characteristics of value chains fundamentally determine the corporate as well as the macroeconomic performance of the economic sectors and industries. Moreover, the direct and indirect economic-dynamising impacts of the industries also highly depend on these links. Overall, the specialisation in certain branches demand a deeper than ever research on the value chain features, owing to the peculiar forward and backward linkages.

The value chain approach is based on the process view of production, where the various subsystems are all connected to each other presenting transformation processes and output. The efficiency of value chain activities determines the costs and profits of the firm (Porter 1985). Many value chains do not confine themselves to a country, which gave rise to the emergence of international or global value chains (GVCs). GVCs have proliferated in the global economy in the last decades. According to De Backer - Mirodout (2013: 8) "A global value chain involves all the activities that firms engage in, at home or abroad, to bring a product to the market, from conception to final use". The production of more and more industries is carried out in GVCs, where an increasing number of countries and locations are involved in the production of a good or service, depending on the technical fragmentation of production, the tradability of intermediary goods and related services, and the level of trade liberalisation of industries at various (regional and global) levels. Owing to these factors, the level of geographic dispersion of the activities of individual industries is different, though changing over time.

The pharmaceutical industry played a special role in the Hungarian economy and economic history throughout the $20^{\text {th }}$ century. At the same time, it is an intelligent industry performing relatively high value added with a constant demand 
for high level human resources and technological infrastructure. Moreover, the pharmaceutical industry used to be and it is a successful, high brand sector both domestically and in the international markets.

The aim of this paper is to detect and reveal the specialities of the Hungarian pharmaceutical industry both in space and time by a value chain analysis. In order to do so we have identified the following research questions:

- What is the position of the pharmaceutical industry in the Hungarian economy in terms of output, value added and expenditure?

- What characterises the pharma industry in terms of its domestic backward and forward linkages?

- What is the international trade performance of the industry?

- What features can be detected regarding the international backward and forward linkages via trade, with special attention to the value added and import content of export as well as the country-industry structures of the upward and downward chains?

- What historic and technological reasons can explain the revealed structure of the Hungarian pharmaceutical industry?

The research is partly quantitative; it monitors the local as well as the international linkages by an input-output analysis. Interviews with the pharmaceutical company representatives enrich the data and the calculations through a better understanding of the figures and the individual company features. Moreover, the Hungarian results are embedded in a general industry overview as well as they receive a historic perspective so that the dynamic approach could support a detailed, nonetheless, comprehensive pharma value chain research.

The paper is structured as follows. We show the industry environment and background: the most important characteristics of the pharma industry in general and the Hungarian pharma industry in particular in Section 1. Section 2 summarises the results of the literature concerning the analysis of the value chains at the industry level and in the pharma industry. Following the applied methodology, Section 3 of the paper presents the quantitative and qualitative analysis (company interviews) and Sections 4 and 5 show their results. The conclusions contain the most important findings in Section 6.

\section{OVERVIEW OF THE PHARMA INDUSTRY}

The pharma industry is specialised in highly technology intensive activities, with the highest R\&D per output indicator among manufacturing industries. Nowadays, the pharma industry is highly globalised and the value chains are reorganised at the international level (Haakonsoon 2009). The industry is moving towards a new 
model, where first, profits are significantly lower than in the previous era, second, connected to that, there is an ongoing consolidation, mainly through mergers and acquisitions. Thus, the main global players are those large pharma firms which have been created in a process of mega mergers and acquisitions, including cross-border ones. The link between these two phenomena, i.e. lower profits and mega mergers and acquisitions, can be traced in the previously high product prices based on the exceedingly high costs of product (molecule) development. With the expiry of previous patents (and the appearance of new competitors with generic products), companies strive to find new molecules, a process which is increasingly costly. Thus, a firm either outsources basic R\&D or tries to find small firms with potentially successful molecules. In these new circumstances, pharma companies from the "mid-developed" countries, such as Hungary cannot really compete with the Big Pharma (leading pharma companies of the developed countries) because of their limited resources (Antalóczy - Sass 2018).

The product of the industry, medicines, is a special good. One of their most important characteristics is that they should be safe and effective. That is why the industry is highly regulated and firms must fulfil a series of requirements, both concerning the production processes and the introduction of a good on the market. These regulations are still mainly at the national level, resulting in a highly fragmented global market (Haakonsoon 2009). Another important feature of the industry is that the production of an active agent or substance consists of thousands of processes, resulting in a long value chain. At each step the company, in principle, may decide about keeping it within the company or outsourcing it to an independent firm. However, because of the highly innovative nature of the industry and because of producing a product for which quality and health security issues as well as the regulatory requirements are of paramount importance, a large part of the value chain is "kept" within the companies. (The regulatory requirements make the process of involving "outside" firms more burdensome than in other industries.) As a result, the pharma value chain is highly standardised and vertically integrated. Thus, the backward and forward linkages of the pharma industry are negligible compared to other industries, especially in production.

One must mention one more specialty of the pharma industry: the distinction between original and generic pharma producers, which differ from each other in many respects (Frew et al. 2015). Original pharma producers invent, develop, patent and produce their own "original" molecules. Generic pharma producers are allowed to produce and sell the same chemical substance after the expiry of the patent of the original drug. After the expiry of the patent, when generic drugs enter the market, prices usually fall for both the original product and its generic equivalents. Obviously, the two types of pharma firms differ from each other in many characteristics. Original pharma producers spend considerably more on 
$\mathrm{R} \& \mathrm{D}$, their value chain is much longer (involves more steps, due to the higher complexity of their activities, a higher number of various regulations to be met and so on) (See Annex). Thus, in principle, the issue of outsourcing and cooperation with economic and non-economic actors may come up more frequently, compared to the generic producers, and could result in a more intense contact, and, thus, effect with and on the economy.

This short introduction to the pharma industry serves to underline the fact that compared to other industries, pharmaceuticals have a large number of special features.

\subsection{The Hungarian pharma industry}

Hungary has a long tradition in pharmaceuticals which dates back to the beginning of the $20^{\text {th }}$ century. Three of the four leading pharma companies (Richter Gedeon, Chinoin and Egis) were established between 1901 and 1913, while one of the predecessors of the fourth (Biogal) in 1950. They are specialised in different areas: Richter Gedeon in pharma production based on natural materials, Chinoin in synthetic pharma production and Egis in nutrition products. After World War II, the pharmaceutical tradition was further reinforced during the $\mathrm{CMEA}^{1}$ area, Hungary being specialized in the socialist division of labour in the production of drugs and being responsible for supplying drugs to other CMEA countries (Antalóczy 1999). Thus, the industry was highly export-oriented, mainly towards the CMEA markets, but could sell some of its products in other countries as well. In the pre-1989 period, basic research was carried out by academic institutions and applied R\&D was assigned to industrial branch research institutes (Felker et al. 1997). There were six major companies operating in the industry (the above mentioned four plus Humán and Alkaloida, smaller-sized and highly specialised), due to the nationalisation and merger of smaller companies into larger ones at the end of the 40s, specialising again in various areas, partly now related to the CMEA needs. Furthermore, in the planned economy period, these firms were all characterised by a very strong level of vertical integration, and even other activities formed part of the company structure, which in market economies are generally outsourced to independent companies (for example, catering, maintenance services, horticultural services, kindergarten and crèche services for the children of the employees). Furthermore, this feature was reinforced by the autarchic nature

The Council for Mutual Economic Assistance (CMEA, but colloquially called also as COMECON) was the economic organisation of socialist countries between 1949 and 1991, organising and regulating trade among the participating countries at the state level. 
of the planned economy, whereby what could be produced locally, was produced there, regardless of the costs. The protection of patent rights evolved in Hungary towards the generic structure, thus the processes of producing a molecule, and not the molecule itself was protected and patented. This type of research specialisation and special knowledge characterised the Hungarian pharma R\&D at that time. When they started to export to outside the CMEA, starting from the 70s, the companies had to fulfil international safety regulations, which again reinforced the trend of keeping the overwhelming majority of production and productionrelated activities within the firm in order to be able to control them.

At the beginning of the transition period, liberalisation of foreign trade, and thus, market access provided to the competitive Western firms significantly reduced the domestic market shares of these companies. Furthermore, as being among the most attractive firms, the government decided to privatise the leading firms to foreign investors, resulting in a strong foreign presence in the industry. Among the six firms, only Richter Gedeon was kept under domestic control (but in dispersed foreign majority ownership) as its shares were introduced on the Budapest stock exchange. The other five companies were sold to foreign pharma firms.

Besides the long tradition, the contribution of the pharmaceutical industry to the Hungarian economy is well above the regional average (Table 1). The industry in Hungary is among the top employers and investors. The ratio of its share in manufacturing production and value added shows that the activities can be characterised as highly complex. Its productivity indicators are also leading in the region.

Nowadays, the characteristics and value chains of the Hungarian pharma companies are, thus, determined on the one hand by their heritage from the planned economy period (path dependency), and on the other hand by the different ways they were privatised. Their privatisation was different from that of other firms, as the pharma firms could maintain their integrity (only those activities were separated which did not have a close connection with pharma production, such as production of cosmetics or pesticides, and in certain cases "auxiliary services" to the employees, such as the kindergarten). Thus, the whole vertical integration of pharma production was privatised, and their future was determined by the new owner.

In the case of Chinoin, the French Sanofi, one of the largest pharma firms in the world first acquired a minority, then a majority, and later full ownership of the Hungarian firm. Sanofi is one of the leading original producers, but it has a generic arm, too. The new owner has gradually changed the vertically integrated value chain of Chinoin. Their R\&D activities were transferred to other (foreign) affiliates; the Hungarian affiliate received the process development of chemical 
Table 1. Selected characteristics of the Hungarian pharmaceutical industry in international comparison (2017)

\begin{tabular}{l|c|c|c|c|c}
\hline & Austria & Czechia & Hungary & Poland & Slovakia \\
\hline Number of enterprises & 89 & 86 & 92 & 350 & 34 \\
\hline Production value (million EUR) & 4130.3 & 1380.2 & 3237.5 & 3754.6 & 185.1 \\
\hline $\begin{array}{l}\text { Wages and salaries (million } \\
\text { EUR) }\end{array}$ & 767.3 & 153.2 & 440.2 & 392.6 & 33.1 \\
\hline $\begin{array}{l}\text { Gross investment in tangible } \\
\text { goods (million EUR) }\end{array}$ & 269.9 & 76.3 & 264.8 & 164.2 & 15.1 \\
\hline Persons employed & 14860 & 10083 & 18928 & 22634 & 2287 \\
\hline $\begin{array}{l}\text { Share of production value in } \\
\text { manufacturing total (\%) (2016) }\end{array}$ & 2.3 & 0.8 & 3.2 & 1.3 & 0.3 \\
\hline $\begin{array}{l}\text { Share of VA in manufacturing } \\
\text { total (\%) }\end{array}$ & 3.4 & 1.2 & 5.7 & 1.7 & 0.5 \\
\hline $\begin{array}{l}\text { Wage adjusted labour } \\
\text { productivity (apparent labour } \\
\text { productivity by average } \\
\text { personnel costs) (\%) (2016) }\end{array}$ & 170.6 & 224.2 & 246.1 & 228.1 & 146.8 \\
\hline
\end{tabular}

Source: Eurostat Annual detailed enterprise statistics for industry (NACE Rev.2).

Note: Manufacture of basic pharmaceutical products and pharmaceutical preparations (C21).

production only - resulting in an almost complete loss of its R\&D activities. Another such area was marketing. What remained at the Hungarian affiliate was generic production (substances, tablets, effervescent tablets, ampules, injections) and the logistics centre. Thus, the value chain has been narrowed down significantly: low value-added activities remained in Hungary, and there were no high value-added ones (re)located here. The value chain has minor links with other industries. Thus, the case of Chinoin can be characterised as a generic value chain with a focus on production.

Biogal was acquired by another leading pharma firm, the top generic producer in the world, the Israeli Teva. Similarly to Chinoin, the value chain was shortened here as well, with production and related development remaining in Hungary. However, the Hungarian company, located in Debrecen is the second largest production site of Teva. Here again, we can speak about a generic value chain with a focus on production.

Richter Gedeon had a different way of privatisation: its shares were introduced on the Budapest stock exchange in three tranches. The main owners are (foreign) portfolio investors, the ownership structure is dispersed, and decisions of strategic importance are made in Hungary by the Hungarian management. The value chain is basically intact from $\mathrm{R} \& \mathrm{D}$ through production till sales. The management of Richter Gedeon organises and outsources-offshores various functions. 
The company is mainly a generic producer, but there is an original "arm" as well, resulting in own drugs. Thus, its value chain is more complex, than in the cases of the previous two companies.

The fourth company, Egis, was privatised to the French Servier. Servier is among the smaller pharma players and is an original company. It has not integrated Egis into its own value chain, as in the cases of the first two companies. It has two separate value chains: generic and original. The generic is organised fully by Egis from development to marketing. In the original, it is rather involved in various activities in the value chain of Servier.

Thus, due to their heritage and privatisation, the four leading pharma companies in Hungary have now different value chain combinations.

\section{LITERATURE OVERVIEW}

The specialties of the pharma value chain are not often analysed in the literature. Related to our article, the analysis of Medina et al. (2017) examines among others the differences of value chains in countries and industries based on industry level data and input-output tables in the European Union (EU) between 2005 and 2014. Industrial value chains are perceived as which contain all value-added in the interlinked industries and countries, through which the ready-made product is delivered to the final users. According to their results, in the EU, individual industries differ from each other in terms of their forward and backward linkages. "Key industries" are those which have strong forward and backward linkages. They found nine such industries, such as e.g. metallurgy, timber, rubber and chemical industry. Those industries belong to the second category which have strong backward linkages and they sell readymade products to households, the government or for investment purposes. There are eight such industries, such as e.g. the automotive, food, machinery, electronics and textile industries. There is one industry with strong forward linkages: the coal industry. From the point of view of our topic, the most important result is that the authors have found one "independent" industry, which has both weak backward and forward linkages - that is the pharma industry. Between 2005 and 2014, there was just a slight increase in the backward linkage index of this industry, and its forward linkage index has not changed at all. The authors have calculated the value-added multiplier of the individual industries, which, in the case of the pharma industry, in spite of the minimal backward and forward linkages, does not deviate significantly from those of the other industries. (It is significantly lower only in the cases of the coal industry and metallurgy.) According to the results of further investigations, at the EU-level, the pharma industry is the third least integrated industry, which 
is obviously in connection with the above described "independent" nature of this industry. At the same time, the indicator of domestic value-added is among the highest for the pharma industry.

Other publications also underline the specialties of the pharma industry, especially its "independent" nature. Sturgeon - Kawakami (2010) concentrated on the electronics industry, but according to the information provided, we can get some hints about the pharma industry compared to electronics. The authors analysed trade in intermediates in eleven manufacturing industries. The share of the pharma industry in the total intermediates' trade of these eleven manufacturing industries was $0 \%$ in 1998, with a value of 0 million USD (thus there was basically no trade in intermediates in our analysed industry), and by 2006 this share grew to $1.7 \%$ only with a value of 66.503 million USD. It is interesting to compare these data with those of the electronics and automotive industries: in 2006 these were $43.3 \%$ and $1,670,940$ million USD; and $21.4 \%$ and 824,392 million USD, respectively.

There are a few country-level analyses about the characteristics of the pharma value chain, leading to results, which reinforce the previous findings. In the case of Ireland, Brennan - Rakhmatllin (2015) analysed this industry based on the trade in value added (TiVa) ${ }^{2}$ database. They emphasize that in the pharma industry there are producer driven value chains, similarly to other high-tech industries. In these value chains, the lead company controls the creation and design of the product and coordinates production shared by many countries (Backer-Mirodout 2013). In the Irish economy, the pharma industry plays an important role. Based on the data they found that among the OECD countries, Ireland is among the first five countries in terms of its participation in chemical GVCs. According to the data, between 1995 and 2009, there has been a significant increase in local value added in Ireland in the export of the industry. While this is mainly due to the upgrading of production companies up till 2005, in 2009, the data indicate a quick growth of local suppliers (intermediaries). The backward and forward participation indexes also support that direction of change. At the same time, the share of services is high (one third) in local value added, the majority of which is fee for intellectual property (royalty). (This latter may indicate the inflating impact of the favourable Irish regulations on the data (Antalóczy - Sass 2014).) In terms of the distance from final demand, the Irish indicator is relatively high in international comparison, thus Ireland has specialised in the production of inputs and not in assembling, which is more beneficial in the case of the producer-driven value chains in terms of local impact and value added. Another positive indicator from the point of view of the Irish economy is that the number of production

2 https://www.oecd.org/sti/ind/measuring-trade-in-value-added.htm 
phases has grown between 1995 and 2009. However, because of methodological problems (TiVA presents aggregated data for the Chemical industry), we have to be cautious with these results.

There is another country level study on the GVC-related characteristics of the pharma industry: for France. Cezar (2016-17) used the WIOD (World InputOutput Database) $)^{3}$ for his analysis. According to his results, the integration of the French pharma industry into global value chains has been realised quickly between 2000 and 2014. This is indicated among others by the quick growth of the import content of exports (from less than $15 \%$ to above $20 \%$ ), which is in line with what we present in the case of Sanofi-Chinoin and partly to Egis-Servier. This indicates mainly the increase in foreign high-tech and mid-tech services. Nevertheless, this integration process seems to come to a halt after the crisis. The integration of the exporting companies is much stronger than that of those firms which only produce for the domestic market. The multinational companies, present on the French market are also better integrated than their French counterparts. In the local (operating only in the French economy) value chains, the contribution of services has declined during the analysed period, the reason for which, according to the author, is the internationalisation of R\&D activities. Overall, the integration in GVCs in the case of the French pharma industry brought with it the increase of the share of foreign value-added in both production and export, at the expense of local value added - which again underlines the description of what happened in the two French-related pharma privatisations in Hungary.

In a most recent study, Folfás - Udvari (2019) analysed the Hungarian and Polish chemical industries in terms of their participation in GVCs. They showed that, though with a declining tendency over time, pharmaceuticals have large domestic value added compared to other branches of the chemical industry. Overall, the literature is not abundant in the analysis of the pharma value chain, which we attribute mainly to data problems becoming more serious in the era of the globalisation and the internationalisation of value chains. New data sources, such as TiVA or WIOD "provoked" new research in this area, the results of which give support to our previous analysis of the fate of the leading Hungarian pharma companies. Further, we could not find analyses of the CEE pharma industry from the GVC's point of view. Furthermore, the analyses so far have not taken into account the original-generic distinction, in spite of the fact that it may result in completely different outcomes concerning the value chain organisation and upgrading. Our article addresses these gaps in the literature.

3 http://www.wiod.org/home 


\section{METHODOLOGY}

With the proliferation of GVCs, in which more than one country participates in the production of a good, it is more and more difficult to map developments in the value chains of an industry. In the production, more locations from many countries take part, there is a substantial flow of goods and services between them, in many cases there are exports and imports of intermediary products and their further processing. Understandably, the export of a country contains not only the value added produced by local producers, but also the value added, arriving to the country with imported inputs, which are later built in the exported product (or final product consumed locally) (UNCTAD 2013; World Bank 2017). Thus, on the basis of the traditional, country and finished product level production and foreign trade statistics we cannot really detect how a country participates in international production, it is specialised in the production of which products, which industries and activities. ${ }^{4}$

Considering the above described data problems, in our analysis, we rely on a combined methodological approach. First, we make an industry level analysis using input-output tables. The main advantage of using the national input-output tables is their comprehensive handling of the production and consumption processes including foreign links in terms of imports and exports. The input-output system offers the technical relations of the different industries or products both in supply and use, hence the national value chains can be traced. The system links production and trade statistics, which used to be calculated by different methods. One of the main benefits of the tables is the possibility to calculate the inverse matrices (and thus the Leontief matrix), which allows the researchers to detect the indirect effects. One of the main drawbacks is the time-consuming nature of data collection and harmonisation. This is why though there are yearly created supply and use tables, systemic input-output tables are more rarely published - in most cases every 5 years - with a number of years lag (Forgon 2008; Miller - Blair 2009; Meng et al. 2012).

International organisations launched projects to extend the input-output systems to the international level, link and harmonise the national input-output tables. The OECD, World Bank and Eurostat databanks are the most often used. The OECD offers national tables as well as different indicators including the

$4 \quad$ For handling this problem, there are two new databases available, such as WIOD (world inputoutput database), and the TiVA (trade in value added) database, compiled by OECD-WTO. We opted for a combined methodological approach, because data in these datasets are not disaggregated to the required level for the pharmaceutical industry and do not contain indicators important for our analysis. 
inverse matrices and many linked indicators. However, the data base differentiates only 36 sectors, combining the ISIC 20 and 21 categories, the chemicals and the pharmaceutical products. Eurostat provides national tables and input-output coefficients only but differentiates 64 products by CPA classification, hence offers information directly on pharma industry, basic pharmaceutical products and pharmaceutical preparations (C21). The EU initiated the compilation of the World Input-output Database (WIOD), which lacks the calculation of indicators but offers internationally linked input-output tables on 43 countries and $56 \mathrm{sec}-$ tors where pharmaceutical products are also differentiated.

This research is based on the Eurostat input-output tables for Hungary, on the UNCTAD trade statistics and on the WIOD. Though this way the most reliable sheets provided data for 2010 only and we had to neglect several pre-calculated indicators; but the figures in use offer information directly for pharmaceutical products by the same classification.

Our second data source is quantitative: we conducted questionnaire-based, semi-structured interviews with leading managers of Hungarian pharma companies in order to explain and understand the mixed results of our quantitative analysis. Our main aim was to map the value networks of the individual pharma companies. We conducted the anonymous interviews with 10 company managers. Among these, there are Hungarian-owned, controlled and foreign-owned companies. Our questionnaire tried to assess their links to local firms and other actors in three areas: $\mathrm{R} \& \mathrm{D}$, production and other activities (HR-services, marketing, etc.)

These two different methodological approaches supplement each other well and help us to overcome the data problems. We have a general picture about the Hungarian pharma industry based on the data, and then we can show the differences between the different groups of companies (mainly generic-original producer, large-medium and foreign-domestic-owned firms) with the help of the information gained from the company interviews.

Finally, embedding the qualitative and quantitative information into the overall and historic prospective of the Hungarian pharma industry we can conclude some specialities of the pharmaceutical value chains in Hungary.

\section{RESULTS OF THE DATA ANALYSIS}

Rather than discussing all details that can be learned from the input-output analysis, our paper focuses on the information that follows the research questions listed. 


\subsection{The domestic position and the domestic backward and forward linkages of the pharma industry}

In terms of its overall weight, the national input-output analysis $\left(2010^{5}\right)$ indicates that even if the pharmaceutical industry does not have a determining position, its relative contribution is significant (Figure 1). The total ratio, $1.85 \%$, actually means a position in the first third of the 65 industries. The numbers reflect an industry, which has relatively high importance in international relations and in public consumption of Hungary and create relatively high changes in inventories.

The total value added seems to be low both in absolute terms and, in comparison, to the ratio of the total production. However, it should be taken into account that the value-added figures of all industries are quite scattered - the highest value is $9 \%$. Pharmaceutical production takes position in the second quarter of the industries.

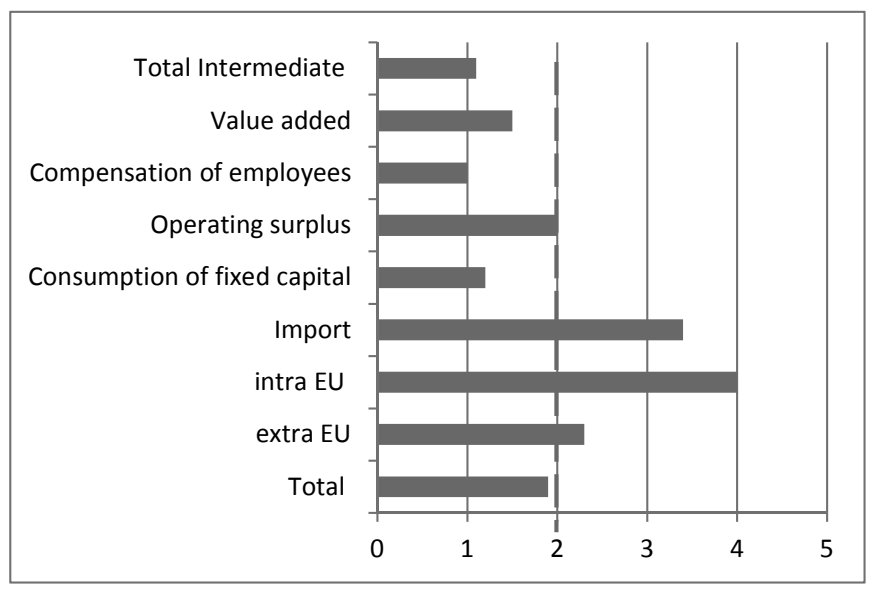

Figure 1a. Ratio of the pharmaceutical supply and use from the total (\%)

Source: Own edition based on Eurostat input-output database. ${ }^{6}$

5 Let us emphasise again that the available and comparative sources of the national and international systemic data for the pharmaceutical industry offered input-output tables for 2010 the latest. However, the value networks prove to keep being stable over the long term and the technological changes have not yet repositioned the industries. Hence the pharma industry specialities can be revealed by the 2010 data, combined with up-to-date interviews.

6 There is no place to analyse and present the whole input-output table and the different industries. The table contains only the numbers of the pharmaceutical industry with reference in the text to its relative meaning among the other branches. 


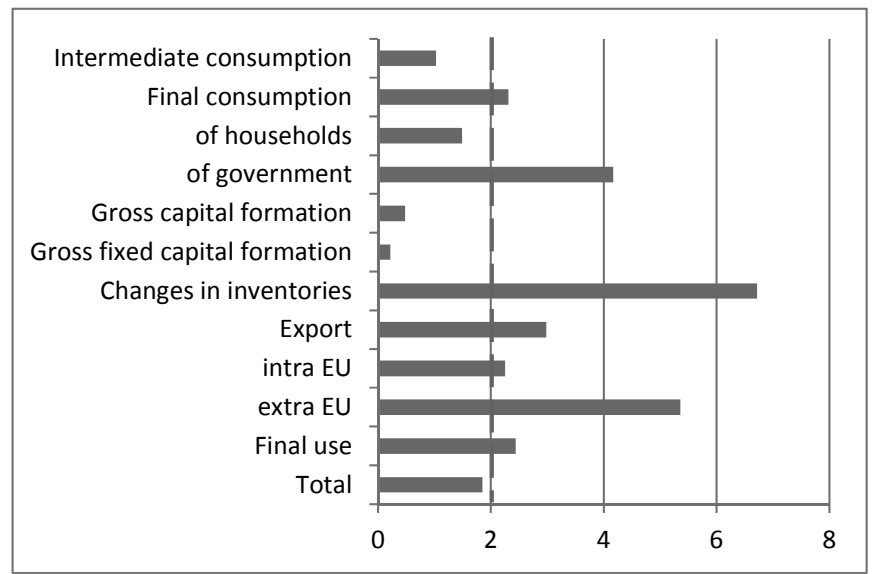

Figure $1 b$. Ratio of the pharmaceutical supply and use from the total (\%)

The inner structure of the pharmaceutical industry (Figure 2) reveals that the pharma industry produces a relatively outstanding share of total value added, one fourth of its production. This share is the highest among all manufacturing industries. One can also learn that both the pharma production and consumption chains are internationally networked to a great extent. Moreover, the industry offers a relatively high profit rate. Though the operating surplus content of the value added exceeds wages, its rate is high at the national level.

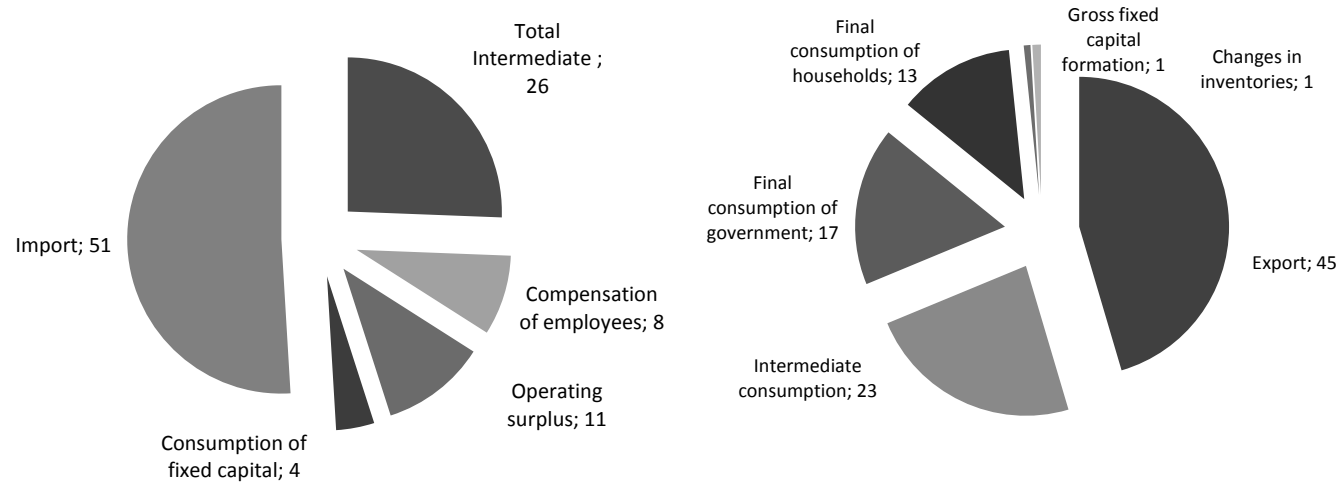

Figure 2. The structure of the pharmaceutical production and use (\%)

Source: Own calculation based on Eurostat input-output database. 
Regarding the length and the structure of the domestic value chains, the technology matrix indicates that the pharmaceutical industry is rather concentrated on relatively few local chains compared to other industries. As for the backward linkages, $20.6 \%$ of the intermediate production is a supply from different intermediaries of the pharmaceutical industry itself, two thirds derive from only 9 different branches, among which three are linked to chemical industries, one is electricity. The remaining industries are different operation services, except for the $\mathrm{R} \& \mathrm{D}$ value chain $(3.4 \%)$, which is both in absolute and relative numbers among the highest values. (Figure 3)

Forward linkages are even more concentrated; just four product groups consume two thirds of the total pharma production. The leading ones are human health services and the pharmaceutical industry itself.

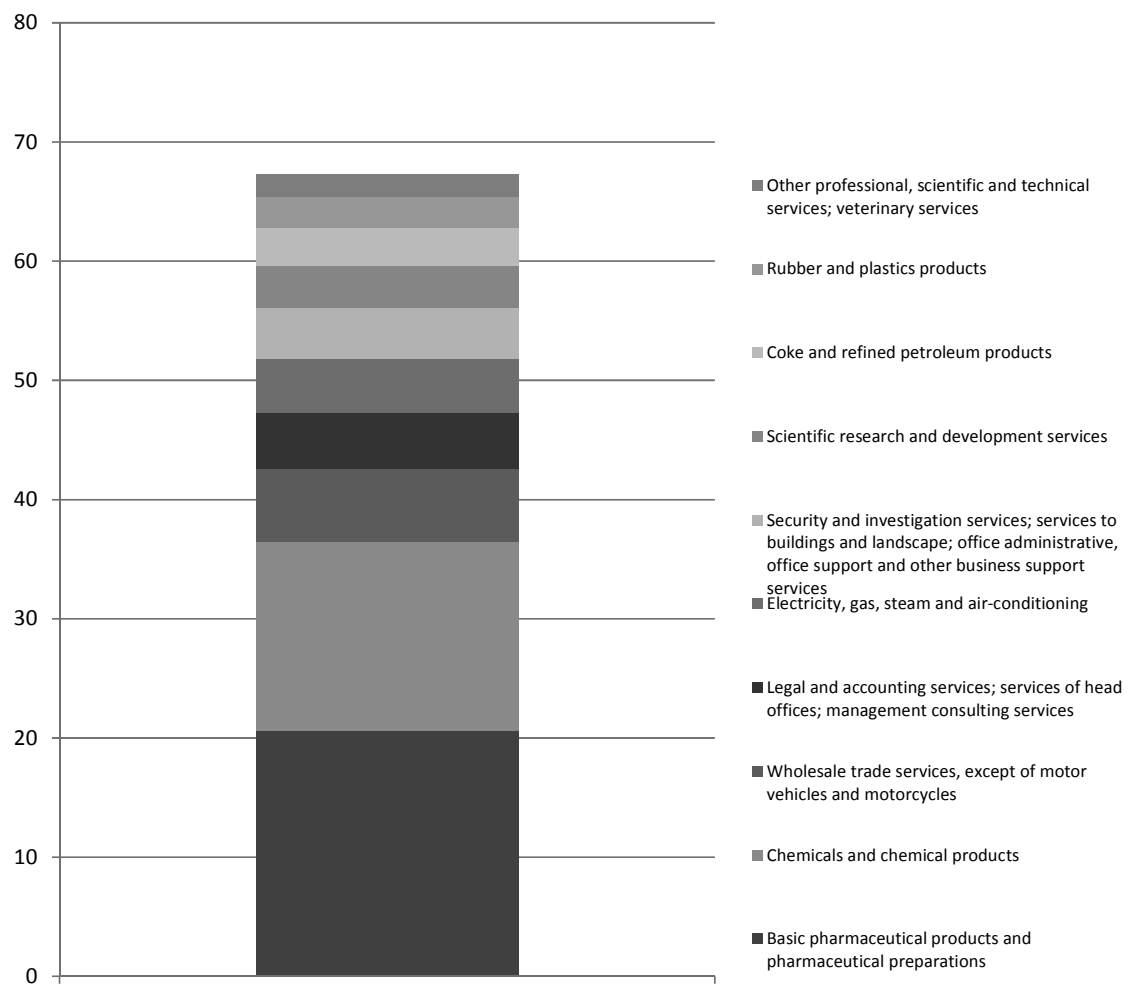

Figure 3. Domestic backward linkages of the pharmaceutical production ( $\%$ of the total intermediaries)

Source: Own calculation based on Eurostat input-output database. 


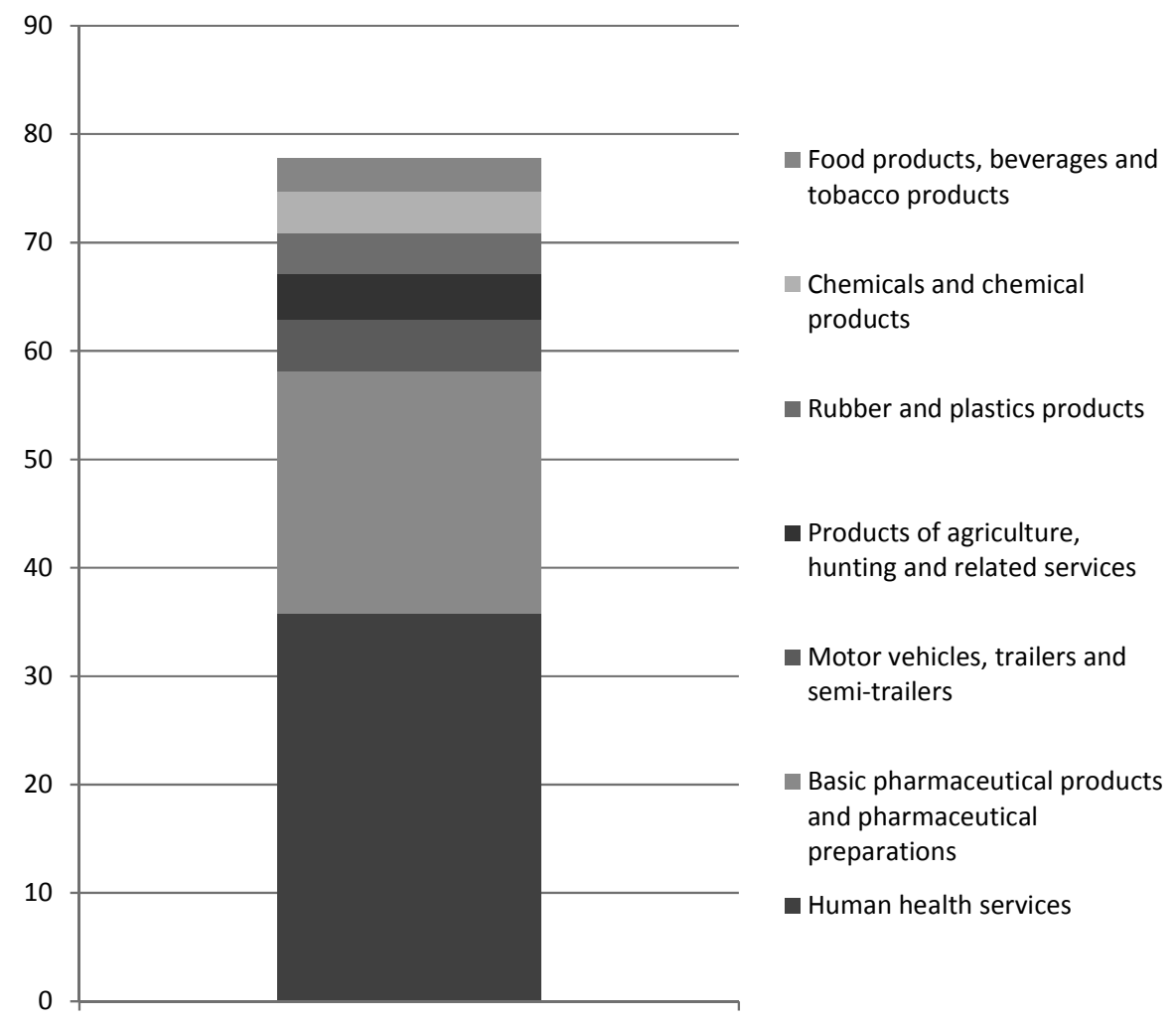

Figure 4. Domestic forward linkages of the pharmaceutical production ( $\%$ of the total intermediaries)

Source: Own calculation based on Eurostat input-output database.

All in all, the domestic input-output figures introduce the Hungarian pharma industry as one which nationally has an important but not outstanding position. Its domestic value chains are relatively short and concentrated with a focused role of the pharma industry itself both in the backward and forward value chains. However, the pharma industry produces the highest value added among the manufacturing industries, and reflects a relatively high research and development ratio. Finally, the total concentrated network is deeply involved in the international value chains both in terms of export and import. We should follow and discuss more on the foreign relations of the pharmaceutical industry. 


\subsection{Trade positions and the international backward and forward value chain links}

To detect the trade positions Annex Table $1^{7}$ lists some important indicators of the pharma trade in a rank of the main industries. Relating to the general economy, the pharmaceutical industry has a moderate participation in overall exports and imports, though it appears among the top ten trading industries in Hungary.

The different chemicals and the related industries all show trade deficits, with relatively low values related to the pharmaceutical products. The time series of net trade in Figure 5 reflects that the permanent deficit position changed in 2010, and until 2016 the industry performance was either balanced or reflected a slight surplus. In 2017, the extent of the value of the backward linkages again overcame that of the upstreaming relations.

Adding the foreign trade coverage ratio, the relatively small deficit with a coverage value lower than but close to 1 , projects a relatively high level of trade flows.

The inter- and intra-industry trade flows offer more information about the value chains of an industry. In the Hungarian economy while the leading industries have high Gruber-Lloyd index: close to 1, meaning a high level of intra-industry trade, the 0.46 value for pharmaceutical products rather reflects inter-industry

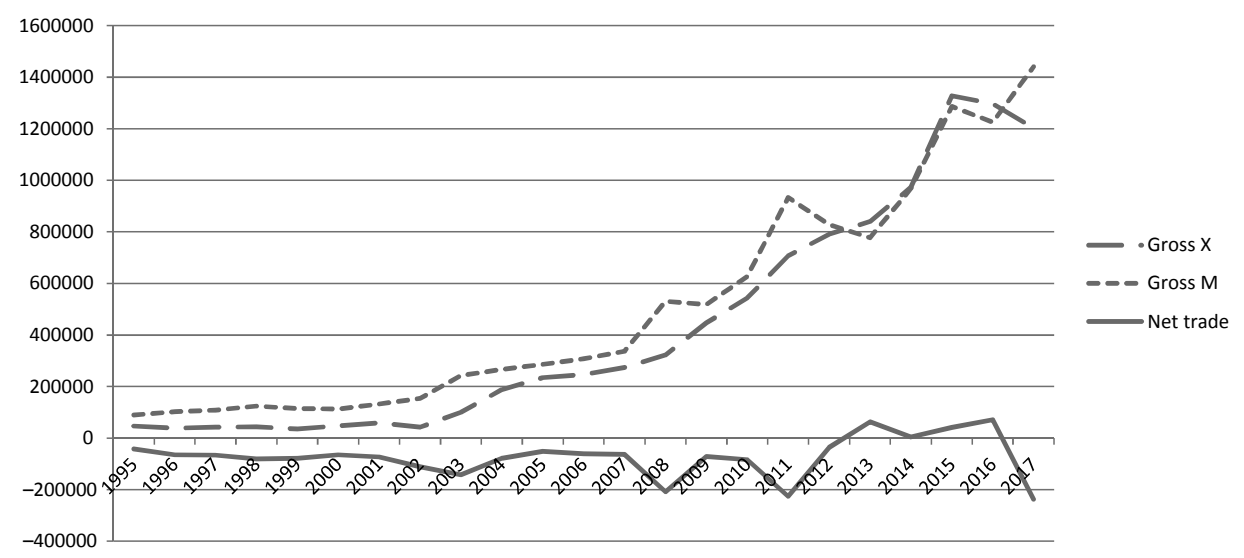

Figure 5. Gross and net trade flows of the medical and pharmaceutical products in Hungary (thousand dollars)

Source: Own edition based on UNCTAD figures.

Some large tables and graphs are put to Annex so that they do not break the continuation of the discussion. 
trade dominance. It seems that while some determining industries produce in long value chains, such as computers, motor vehicles and even rubber and plastics in chemical industries, the pharmaceutical production chain rather shrank.

The Balassa Revealed Comparative Advantage (RCA) indicates that Hungary has a very slight comparative advantage in medical products. Figure 6 shows the evolution of RCA over time. After the transition process started, there was a fall in pharma exports, due to privatisation and the collapse of the Russian market. The specialisation in pharmaceutical products has increased since 1995, mainly in the case of medicaments. However, even if RCA is taken usually as an indicator of comparative advantage, the increasing relative ratio does not necessarily mean an increasing value added content of export; hence the domestic value added may even fall due to the increasing import of intermediaries and the engagement of production factors in low value added products and chains.

Linking the supply and demand sides of the national input-output accounts enables to detect the value added and import content of export (Table 2). The technological coefficients and the Leontief inverse matrix reveal that regarding the direct domestic relations of the industries, the pharmaceutical value added of export is quite low, only $8 \%$, while the national average is $19 \%$. However, considering the indirect relations too, the domestic value added content of pharmaceutical exports reaches $35 \%$, the highest among the leading manufacturing industries. This means that even if the pharma industry has a relatively high value added content, the majority of the value added export comes from the backward chain industries.

The international value chains of pharmaceutical production also depend on how the import content of supply contributes to export. The direct and indirect

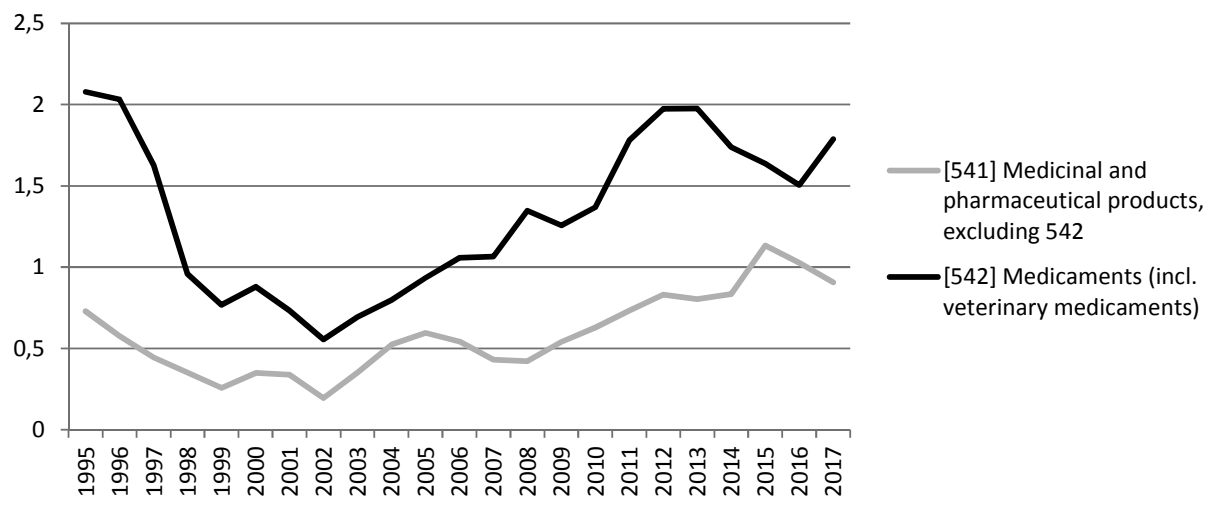

Figure 6. Change in RCA of pharmaceutical products

Source: Own figure based on UNCTAD data base. 
Table 2. The main backward and forward linkages of the pharmaceutical production by industry in terms of import ( $\%$ of total)

\begin{tabular}{|c|c|c|c|}
\hline \multicolumn{2}{|l|}{ Imports to pharmaceutical supply } & \multicolumn{2}{|c|}{$\begin{array}{l}\text { Sectors importing pharmaceutical prod- } \\
\text { ucts }\end{array}$} \\
\hline $\begin{array}{l}\text { Basic pharmaceutical products and phar- } \\
\text { maceutical preparations }\end{array}$ & 27.1 & Human health services & 34.2 \\
\hline Chemicals and chemical products & 21.2 & $\begin{array}{l}\text { Basic pharmaceutical products } \\
\text { and pharmaceutical prepara- } \\
\text { tions }\end{array}$ & 27.0 \\
\hline $\begin{array}{l}\text { Wholesale trade services, except of motor } \\
\text { vehicles and motorcycles }\end{array}$ & 6.1 & $\begin{array}{l}\text { Motor vehicles. trailers and semi- } \\
\text { trailers }\end{array}$ & 5.7 \\
\hline $\begin{array}{l}\text { Legal and accounting services; services } \\
\text { of head offices; management consulting } \\
\text { services }\end{array}$ & 5.9 & Chemicals and chemical products & 4.1 \\
\hline $\begin{array}{l}\text { Security and investigation services; services } \\
\text { to buildings and landscape; office admin- } \\
\text { istrative, office support and other business } \\
\text { support services }\end{array}$ & 5.4 & & \\
\hline Scientific research and development services & 4.6 & & \\
\hline
\end{tabular}

Source: Own compilation based on the import matrix of Eurostat input-output tables.

import ratio of export is $64 \%$, which means that two thirds of the export value of the pharmaceutical products comes from direct imports as well as from imports used in the production of domestic intermediaries.

The import matrix (Table 2) reveals the internationally linked backward and forward industries of the pharma value chain. Similar to the national value chains, the industry is linked internationally to pharmaceutical and to other chemical products. This represents almost half of the import. The rest consists mainly of other chemical products and different services; however, it is worth noting the relatively high proportion of the foreign $\mathrm{R} \& \mathrm{D}$ contribution. As far as pharmaceutical consumption is concerned, we have found that about one third of the total pharmaceutical import is used in the production of other industries; of which Table 2 indicates that human health services as well as the pharmaceutical industry itself consumes the most.

The international input-output databases and the calculated inverse tables offer even more new insights. They make it possible to involve the different countries by industries to detect the downward and upward linkages (Annex Tables 2 and 3$)^{8}$. The overall learning is that both the backward and forward linkages are

It is important to note that the WIOD table is based on industry $\mathrm{x}$ industry, while the Eurostat data were product $\mathrm{x}$ product based. The Hungarian figures and ratios hence differ from the earlier tables. 
scattered among a number of countries but they are more concentrated in terms of values. In the backward links, the European, mainly Hungarian and German chemical and service industries dominate. The forward chains reach out mostly to the USA, Russia and China, where pharma products for final consumption dominate rather than intermediaries. The details are as follows: The international production (backward) chain of the pharmaceutical products of Hungary consists of 300 different units in 36 different countries. Most of them are from Europe, outside Europe the USA leads (6 industries), followed by Korea (5), Japan (2), Taiwan (1) and Russia (1). The dominant countries are European: Hungary (49) and Germany (27), followed by Austria (16), Poland (15) and Italy (15). Among the industries, 19 are manufacturing, mostly chemical (32), pharmaceutical (24) and rubber (17). However, the majority are services, mainly wholesale trade, legal and accounting services.

Though the number of chain links is high, by value it is more focused: one third of the total output comes from 9 sources only, mainly from Hungarian and German industries. It is interesting to see that in Hungary mostly the service sector contributes and then the chemical industry. The other countries list their pharmaceutical or chemical industries in the following country order regarding intermediary values: Germany, Switzerland, Austria, France, Czech Republic, Great Britain, Italy, Belgium, Russia and the Netherlands ( $75 \%$ of the total value).

As far as the forward chain is concerned (Annex Table 3), 326 different units are present in 40 countries. On the export side, more non-European countries appear, USA (14 units with 12 industries among them), Russia (12) China (5) Canada (3), Brazil (3), Indonesia (3), Australia (2) and Japan (2). There are more dominant countries in terms of the number of chain links: Hungary (42 industry +4 final use), Italy (19+4) and Germany (17+4), then Poland (12+3), France $(11+3)$, Czechia (10+3), Romania (10+3), The Netherlands (10+3), Slovakia (7+4), Austria $(7+3)$ and Denmark $(6+4)$. However, the forward links are also concentrated: 5 links give the first third of the total value and 11 represent $50 \%$. It is remarkable that $75 \%$ of the total value mainly consists of final consumption; only Italy, Czechia, Switzerland and Great Britain import Hungarian pharmaceutical products for human health or pharmaceutical manufacturing.

All in all, the international input-output analysis revealed more pharma industry specialities. The industry is foreign market oriented to a great extent both in terms of export and import. However, the value-added content of export is relatively low and can mainly be derived from the foreign backward industries. The $R \& D$ content of the industry's value added is relatively high, though its majority is also concentrated in the backward value chains outside the country. The international backward and forward linkages are quite concentrated both domestically and internationally, though not to the same extent in terms of countries and 
industries. On the backward side the European countries, mainly Germany and Austria, dominate, while regarding the forward linkages, the importance of the non-European partners, such as US, Russia, China is relatively higher.

These results indicate a characteristic industry profile. However, the historic overview highlighted that the main traditional pharmaceutical companies were launched with different specialisation, followed different production patterns and they were privatised in different ways. Hence our research must not neglect the individual features, or more precisely those characteristics that differentiate the main companies from each other and contribute to a detailed value chain analysis. We need to turn to the primary sources of our analysis: to the interviews in order to detect further industry specialties.

\section{RESEARCH RESULTS BASED ON COMPANY INTERVIEWS}

In order to partly explain and partly supplement the results of the quantitative analysis, we took anonymous interviews with ten pharma managers, where we tried to enquire about their contacts with local and foreign economic and noneconomic agents. Our questionnaire tried to assess these links with domestic firms and other actors in three areas: R\&D, production and other activities (HRservices, marketing, etc.). In our sample, we had all the leading pharma firms in Hungary (four companies, all majority foreign-owned, one domestically controlled), four medium-sized Hungarian companies, and two small-sized biopharma firms. Furthermore, we have conducted an interview with the representatives of MAGYOSZ, the association of Hungarian pharma firms.

Table 3. Basic characteristics of the interviewed companies (2017)

\begin{tabular}{c|c|c|c|c|c}
\hline & $\begin{array}{c}\text { Majority } \\
\text { ownership }\end{array}$ & Size & Original - Generic & $\begin{array}{c}\text { R\&D expenditure/ } \\
\text { sales, \% }\end{array}$ & $\begin{array}{c}\text { Export/ } \\
\text { sales, \% }\end{array}$ \\
\hline $\mathrm{A}$ & foreign & large & original/generic & 9.1 & 90 \\
\hline $\mathrm{B}$ & foreign & large & generic & 8.5 & 77 \\
\hline $\mathrm{C}$ & foreign & large & generic/original & 22.5 & 32 \\
\hline $\mathrm{D}$ & foreign & large & generic & 1.0 & 84 \\
\hline $\mathrm{E}$ & domestic & medium & generic & 15.0 & 13 \\
\hline $\mathrm{F}$ & domestic & medium & generic & 2.0 & 87 \\
\hline $\mathrm{G}$ & domestic & medium & generic & 3.0 & 19 \\
\hline $\mathrm{H}$ & domestic & medium & original (biotech) & 40.0 & 99 \\
\hline $\mathrm{I}$ & domestic & small & original (biotech) & 12.0 & 9 \\
\hline
\end{tabular}

Source: Authors' compilation (data from the balance sheets and supplements of the companies). 
Our interviewed managers reinforced the observations about the differences between the original and generic value chains. The original value chain is more complex, longer and in principle involves more links with other companies and industries-activities. The difference between the two value chains can be found mainly in the first phase: the R\&D activities of the original companies and activities involve more stages, are more complex and embrace a longer time period. They require extensive relationships with research institutes, universities, other firms and clinics. The generic value chain is shorter, less complex and has a lower number of links outside of the company. As we already noted, the Hungarian pharma producers are mainly generic ones. The manager of firm "A" underlined that in companies, where both generic and original activities are present, the value chains of the two are treated separately, they are separated from each other from the organisational point of view as well. In the case of company "B", the foreign owner of which is a company with both generic and original profile, this means that the parent firm has the whole original value chain, while the generic one "belongs" to the Hungarian affiliate, involving all activities from generic $\mathrm{R} \& \mathrm{D}$, through production, sales to marketing. Decisions of strategic importance are taken by the foreign owner, thus the Hungarian pharma producers' domestic value chains and the related linkages are determined by their ownership structure and the strategy of their owners. As the manager of company "A" noted: "The development and marketing of a molecule consists of thousands of different steps. Each step involves a decision: whether to keep it within the company or outsource it?" In the case of company "C" - in a similar situation, in the ownership of a foreign multinational company with both generic and original production - the owner has reorganised the value chain many times in the last 30 years. At present, the Hungarian affiliate retained only a part of the generic value chain, production. The first part of the value chain, R\&D activities have almost completely been transferred away from Hungary, while the parent company established the CEE logistics centre here, and from the last parts of the value chain, only the Hungaryfocused marketing remained here - even this latter in a special organisational construction. In the case of company " $D$ ", the parent company has just a generic profile. For its Hungarian affiliate, it "cut" the first and last parts of the value chain, and basically just the production activities remained in Hungary. At the same time, this part of the value chain has been developed to an extent where the Hungarian affiliate is the second most important production site in the network of the multinational firm, and thus, it is of strategic importance. Company "A" has both generic and original value chains, both of them in a very complex form, because the Hungarian management decides about the value chain activities due to the dispersed ownership structure of the company. Thus, in the case of the four leading firms, the relationship with and links to other firms and industries is 
determined by the length, complexity and nature of the value chain in Hungary and the strategy of the management. In the case of the other interviewed smaller firms, generic activities dominate; they concentrate on a few products compared to the big firms, with shorter and less complex value chains.

In principle, the highest number of linkages with firms is available in the R\&D phase, especially in the case of the original companies. This was reinforced by the interviews: we found the strongest and most frequent cooperation links in the area of $\mathrm{R} \& \mathrm{D}$, in many cases with local companies, or other local institutes (universities or public and private research institutes). However, by far the highest frequency was found in the case of company "A", which has both generic and original arms.

We found many cases when outsourcing of certain R\&D activities was realised. Similarly, the large pharma firms, which have intensive R\&D, indicated that they outsource basic research activities to universities, research institutes or small biotechnology firms. Medium-sized firms had a similarly intensive outsourcing of $R \& D$, one firm in our sample even indicated that the value of within and outside company $R \& D$ is similar. Smaller firms have similarly close cooperation links in $\mathrm{R} \& \mathrm{D}$, however, in their case they carry out such activities for other firms as well. Company "E" for example, a medium-sized Hungarian pharma firm, with technology-related R\&D, outsourced measuring activities to a Hungarian university and cooperates with various Hungarian universities. To a limited extent, they carry out R\&D activities for Hungarian and foreign pharma firms. A small firm in our sample, company "I" is actively seeking for outsourced activities from large pharma firms, and the revenues from these activities are used for financing own R\&D of the small firm. The companies in our sample regarded clinical trials as part of R\&D activities. In this area they had intense links with foreign-owned companies operating in Hungary, with Hungarian companies and in certain cases with those hospitals (or workers of hospitals) which provide such services. For example, one firm in our sample, company "G" outsourced clinical trials related IT activities to a Hungarian company. Basically, all companies evaluated these $\mathrm{R} \& \mathrm{D}$ links as long-term, though in certain areas and with certain economic actors they have short to medium term cooperation. However, long-term cooperation dominates. Almost all cooperation partners receive various help: mainly trainings, quality insurance, donation of equipment, providing information or advice. Only one company was an exception in our sample, according to which this help was negligible from its partners. All companies are members of various industrial or other chambers or associations in Hungary, which helps them in finding partners for outsourcing and cooperation.

As for the intensity and importance of these relationships: we asked whether the loss of these would impact upon the company's operations strongly. All com- 
panies in our sample indicated a strong impact, however, the strength of this correlated negatively with company size: the larger the company, the smaller the impact.

The other area of the analysis of local links was production - whereby we could not trace the same intensity and frequency of local cooperation as in the case of $R \& D$ - reinforcing our results for the importance of the $R \& D$ part of the value chain in terms of local impact. The companies in the sample rely to a very limited extent on local suppliers, which is partly due to the above described 'shortness' of the value chain, as the companies keep the majority of the value chain within them. Among the suppliers we can find producers of packaging material, producers of specialised machinery, chemical firms, and suppliers of raw materials. For example, company " $\mathrm{H}$ " in our sample buys packaging foil, boxes and alcohol from Hungary, and the molecules from abroad. None of the interviewees quantified the value of various inputs, but all of them indicated that they are of minor importance. In all cases, the share of local suppliers is dominant, above $60 \%$. However, in many cases the substances originate from abroad. One foreignowned firm, company " $\mathrm{B}$ " mentioned that many traditional suppliers of the parent firm established a subsidiary in Hungary to provide local supply, so we can assume that in the case of the other firms, such local supplies (by foreign-owned companies) are also important. The companies hardly bought high-tech products from these suppliers, with the exception of one interviewed firm. According to the opinion of managers, they all ranked the importance of production-related links and partners lower compared to R\&D. This low role of local suppliers in production can be explained partly by the high requirements concerning the suppliers. Quality requirements are high, and they require a complex quality insurance system. Furthermore, flexible delivery time and financing constructions are also needed. In the 90s, many traditional Hungarian suppliers could not bear the intense competition, and thus, there has been an increase in imported supplies. According to our interviewees, in the nineties, the group of suppliers was not stable; however, since then there is a stabilisation in this respect. Interestingly enough, the composition of suppliers, according to the ownership (foreign and domestic) is determined not by the ownership structure of the firm in question, rather by its product structure (Antalóczy 1997). As our interviewees noted, requirements and regulations of the export markets and whether the finished product dominates, determines this composition. For export markets with high requirements, good quality inputs are used, which are in many cases imported from abroad.

Similarly, less intense and less close is the partnership with suppliers in other areas. For example, in the area of services, certain services are acquired from local suppliers in the case of all companies both regularly (infrastructure and office maintenance) and occasionally (HR and headhunting). We could put clinical tri- 
als in this category as well. These are present in all company cases, with varying intensity. The smaller sized firms choose mainly local(ly available) suppliers, while the large ones choose the leading companies in the area. One must also mention partnership with trading firms. However, overall, these partnerships are of lesser importance for all firms.

\section{CONCLUSIONS}

Our input-output analysis supported the common knowledge that the pharmaceutical industry has a significant position in the Hungarian economy. It has an important share in output, in export and even more in import. Specialisation in the pharma products has increased since 1995 as well as a slight comparative advantage can be detected. The industry's gross trade flow is considerable with strong positions in the imports though less determining in the exports.

The value added content of the production is relatively high with a proportionally greater share of operating surplus in contrast to wages. As far as the industry specific production structure is concerned, the value chain of the pharma industry is different from those of other industries. Its technological relations do not demand and its highly regulated nature does not allow a wide range of backward or forward linkages. The domestic value chain structure in Hungary is quite concentrated with a few local chains only. The input-output data reflect that the inter-industry (chemical) backward relations of the pharma industry are relatively high. The forward linkages are even more focused: most of the output appears in the final use, mainly among health services and partly in export.

The international links of the Hungarian pharma value chains are also concentrated both in terms of inter-industry relations and of the partner countries. The majority of the backward links run via Central Europe, mainly in Hungary and Germany. The international forward value chains spread among more countries; however, still remain concentrated, and the destination is mainly the nonEuropean final consumption.

The structure of the value chain is also considerable. The pharmaceutical chain is not only short but also uneven in terms of the value added. Even if the pharmaceutical export has relatively high value content, two thirds of it derives from the direct and indirect import. The figures support that the domestic contribution to the value added is quite low. The type of the value chain further distinguishes the value added content and the possible participation in the production. The interviews highlighted that the value chains of the original and the generic production processes essentially vary. The original value chains are longer and more complex with a high $R \& D$ content in the beginning stage. In Hungary, most of the 
pharmaceutical production is generic with a relatively shorter and simpler value chain structure; or in case both the organic and the generic are present, they are separated and mainly the modest value-added production phases of the organic process remain.

The historic embedding contributed much to the understanding of the pharmaceutical specialties. The original companies launched different value chain paths by their special original-generic structure. In the CMEA period, the increase of the value-added potential was highly motivated since the pharmaceutical industry had a special role in the East-West economic strategy. This relative corporate and national wealth turned a new period by the different modes of privatisation. Further division of the relatively short value chain has made the industry even more specific. At the same time, the owners made a selection of the activities in the value chains based on their efficiency and potential, and moved the most promising activities (in certain cases whole chains) outside the country. Thus, the mode of privatisation was of determining importance from the point of view of further development of the Hungarian pharma industry: where same-industry foreign owners appeared, the above changes in the value chain resulted in negative or ambiguous impact on the Hungarian value chain. Further, the Hungarian controlling owners (with foreign majority ownership) could keep full value chains - though mainly generic, only some original - within the country.

\section{REFERENCES}

Antalóczy, K. (1997): A magyar gyógyszeripar versenyképessége - adatok, hipotézisek, töprengések (The competitiveness of the Hungarian pharmaceutical industry - data, hypotheses, speculations). Compete with the World Working Paper Series, No. 17. Corvinus University of Budapest.

Antalóczy, K. (1999): Privatizáció a gyógyszeriparban (Privatization in the pharmaceutical industry - in Hungarian). ÁPV Rt., Budapest.

Antalóczy, K. - Sass, M. (2014): Tükör által homályosan: a külföldi közvetlentőke-befektetések statisztikai adatainak tartalmáról (Through a glass darkly: about the content of statistical data on foreign direct investment - in Hungarian). Külgazdaság, 58(7-8): 30-57.

Antalóczy, K. - Sass, M. (2018): The Internationalisation of Richter Gedeon, the Hungarian Pharmaceutical Company, and Entrepreneurship in Hungary. In: Mets, T. - Sauka, A. - Purg, A. (eds): Entrepreneurship in Central and Eastern Europe: Development through Internationalization. London: Routledge, pp. 159-176.

Blair, P. D. (2009): Input-Output Analysis. Foundations and Extensions. Cambridge University Press.

Brennan, L. - Rakhmatullin, R. (2015): Global Value Chains and Smart Specialisation Strategy. Joint Research Centre, Science for Policy Report. European Commission, EUR 27649 EN.

Cezar, R. (2016-17): France's Pharmaceutical Industry in Global Value Chains. Quarterly Selection of Articles Banque de France, 44: 51-63. 
Dankó, D. (2011): Resource Management in an Industry with Long-term Return - Increasing Efficiency along the Pharmaceutical Value Chain. Corvinus University of Budapest, Institute of Management. PhD Dissertation.

De Backer, K. - Miroudot, S. (2013): Mapping Global Value Chains. OECD Trade Policy Papers, No. 159, OECD Publishing.

Felker, G. - Chaudhuri, S. - György, K. - Goldman, M. (1997): The Pharmaceutical Industry in India and Hungary. Policies, Institutions and Technological Development. World Bank Technical Paper, No. 392, New York.

Folfas, P. - Udvari, B. (2019): Chemical Industry and Value-Added Trade - A Comparative Study on Hungary and Poland. Acta Oeconomica, 69(1): 81-99.

Forgon, M. (2000): Ágazati kapcsolatok a gazdasági modellezésben (Input-output tables in economic modelling - in Hungarian). Gazdaság és statisztika, 51(2): 66-67.

Frew, B. - Frew, J. R. - Swift, C. F. (2015): Competition Between Original Brands and Generics in Pharmaceuticals: Analysis and Policy Implications. In: Bellur, V. (eds): The 1980's: A Decade of Marketing Challenges. Developments in Marketing Science: Proceedings of the Academy of Marketing Science. Springer, Cham.

Haakonson, S. J. (2009): The Changing Governance Structures of the Global Pharmaceutical Value Chain. Competition \& Change, 13(1): 75-95.

Medina, A. - Thompson, D. - Spinoglio, M. - Magalhaes, H. - Esteves, S. - Pinho, F. - Rocha, F. Bilsen, V. - Debergh, P. - Greeven, S. - Kretz, D. - Stehrer, R. - Hanz-Weiss, D. - Siedschlag, I. - Di Ubaldo, M. - Studnicka, Z. - Szalavetz, A. - Sass, M. (2017): Study on Investment Needs and Obstacles along Industrial Value Chains. Brussels: European Commission.

Meng, B. - Fang, Y. - Yamano, N. (2012): Measuring Global Value Chains and Regional Economic Integration: An International Input-Output Approach. Institute of Developing Economies, JETRO. IDE Discussion Paper, No. 362.

Miller, R. E. (2017): Study on Investment Needs and Obstacles along Industrial Value Chains. Brussels: European Commission.

Porter, M. E. (1985): Competitive Advantage. New York: The Free Press.

Sturgeon, T. - Kawakami, M. (2010): Global Value Chains in the Electronics Industry. Was the Crisis a Window of Opportunity for Developing Countries? Policy Research Working Paper, No. 5417. World Bank, Washington, D.C.

UNCTAD (2013): World Investment Report. Global Value Chains and Development Investment and Value Added Trade in the Global Economy. Geneva.

World Bank (2017): Measuring and Analysing the Impact of GVCs on Economic Development. International Bank for Reconstruction and Development - The World Bank, Washington, D.C.

Open Access. This is an open-access article distributed under the terms of the Creative Commons Attribution 4.0 International License (https:/creativecommons.org/licenses/ by/4.0), which permits unrestricted use, distribution, and reproduction in any medium, provided the original author and source are credited, a link to the CC License is provided, and changes - if any - are indicated. (SID_1) 


\section{ANNEX}

\begin{tabular}{|c|c|c|c|c|c|c|c|c|c|c|c|}
\hline 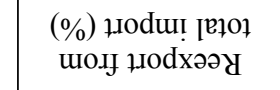 & $\frac{\pi}{4}$ & $\underset{\infty}{+}$ & $\begin{array}{l}\underset{+}{G} \\
\dot{J}\end{array}$ & $\stackrel{\infty}{\underset{+}{+}}$ & $\frac{6}{1}$ & $\begin{array}{c}0 \\
\stackrel{1}{c}\end{array}$ & $\stackrel{\overbrace{}}{i}$ & $\begin{array}{l}\text { ळे } \\
\text { in }\end{array}$ & $\begin{array}{l}\infty \\
\infty \\
\infty\end{array}$ & 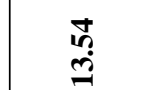 & $\stackrel{n}{n}$ \\
\hline 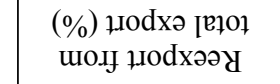 & ñ & $\stackrel{n}{n}$ & $\stackrel{\infty}{\infty}$ & $\begin{array}{l}\mathscr{6} \\
\dot{+}\end{array}$ & 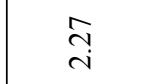 & 售 & $\stackrel{\infty}{i}$ & $\stackrel{\infty}{\infty}$ & $\frac{n}{a}$ & $\frac{19}{19}$ & $\underset{i}{i}$ \\
\hline 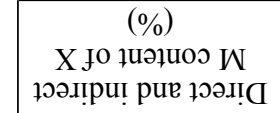 & & $\underset{\hat{i}}{\grave{\infty}}$ & $\hat{\hat{o}}$ & $\begin{array}{l}8 \\
16\end{array}$ & 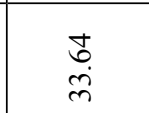 & $\mid \begin{array}{c}\infty \\
\infty \\
i \\
i\end{array}$ & $\begin{array}{l}8 \\
\dot{0} \\
\dot{n}\end{array}$ & $\begin{array}{l}F \\
\stackrel{r}{i}\end{array}$ & $\stackrel{\frac{\pi}{6}}{2}$ & 옹 & $\begin{array}{l}\stackrel{2}{2} \\
\stackrel{2}{r}\end{array}$ \\
\hline 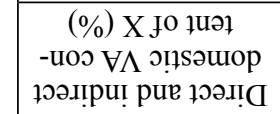 & & $\stackrel{1}{\beth}$ & ふूे & $\vec{m}$ & $\hat{n}$ & $\begin{array}{l}\dot{v} \\
\ddot{n}\end{array}$ & $\begin{array}{l}\qquad \\
o \\
\infty \\
\dot{+}\end{array}$ & $\begin{array}{l}\stackrel{\sim}{u} \\
\ddot{n}\end{array}$ & $\underset{\sim}{\vec{m}}$ & $\begin{array}{l}\text { Lิ } \\
\text { ம் }\end{array}$ & ஜे \\
\hline 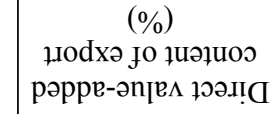 & ֻ̊. & $\vec{a}$ & $\stackrel{n}{n}$ & $\begin{array}{l}\infty \\
\infty \\
\dot{f}\end{array}$ & $\begin{array}{l}\bar{\infty} \\
\infty \\
\infty \\
m\end{array}$ & $\begin{array}{l}\vec{\sigma} \\
\dot{v}\end{array}$ & 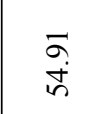 & $\vec{\infty}$ & $\hat{n}$ & $\stackrel{0}{\infty}$ & 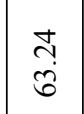 \\
\hline 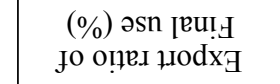 & $\mid \begin{array}{c}0 \\
n \\
\infty \\
\dot{\gamma}\end{array}$ & $\begin{array}{l}\stackrel{2}{1} \\
\stackrel{2}{\Omega}\end{array}$ & $\underset{\infty}{\stackrel{\infty}{\infty}}$ & $\begin{array}{l}\text { Uू } \\
\stackrel{+}{\sim}\end{array}$ & ñ & $\left|\begin{array}{l}n \\
2 \\
2 \\
\infty\end{array}\right|$ & $\begin{array}{l}0 \\
n \\
q \\
q\end{array}$ & $\underset{\substack{\text { } \\
\infty \\
\infty}}{ }$ & $\begin{array}{l}\stackrel{2}{a} \\
i \\
\infty\end{array}$ & 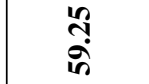 & 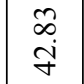 \\
\hline $\begin{array}{c}\text { хәри! } \\
\text { ркоІТ-ләqnıю口 }\end{array}$ & àे & $\hat{\sigma}$ & $\frac{0}{0}$ & $\stackrel{n}{o}$ & $\stackrel{\vec{b}}{\circ}$ & $\hat{a}$ & $\stackrel{n}{o}$ & $\begin{array}{l}\infty \\
\infty \\
0\end{array}$ & $\stackrel{\infty}{a}$ & $\stackrel{\mathscr{0}}{0}$ & 广̊. \\
\hline 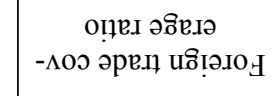 & $\mid \begin{array}{r}n \\
-\infty\end{array}$ & $\stackrel{?}{=}$ & $\stackrel{n}{6}$ & ஓి & $\stackrel{\infty}{\sim}$ & $\stackrel{n}{o}$ & $\stackrel{0}{=}$ & $\stackrel{\circ}{0}$ & $\hat{o}$ & $\stackrel{\mathscr{0}}{0}$ & $\ddot{n}$ \\
\hline 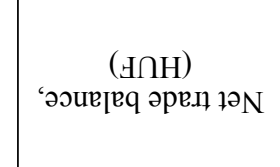 & $\begin{array}{l}\frac{N}{2} \\
\frac{2}{6}\end{array}$ & $\begin{array}{l}\stackrel{0}{\Xi} \\
\stackrel{0}{0}\end{array}$ & 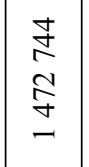 & $\begin{array}{l}\infty \\
\infty \\
\infty \\
\stackrel{\infty}{0} \\
\stackrel{m}{\longrightarrow}\end{array}$ & $\frac{\stackrel{+}{d}}{\stackrel{\infty}{n}}$ & $\underset{N}{N}$ & $\begin{array}{l}\hat{N} \\
\stackrel{\infty}{\infty}\end{array}$ & $\begin{array}{l}\hat{\sigma} \\
\text { Oે } \\
\text { } \\
\text { }\end{array}$ & 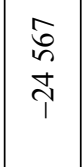 & 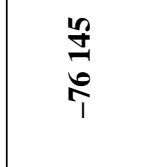 & \begin{tabular}{l}
$\hat{\infty}$ \\
N \\
o \\
\multirow{1}{T}{}
\end{tabular} \\
\hline $\begin{array}{c}\text { (새) } \\
\text { 'Mоц әре.l sso.̣ }\end{array}$ & 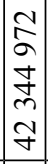 & 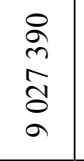 & \begin{tabular}{l}
0 \\
\multirow{1}{*}{} \\
$\dot{J}$ \\
0 \\
0
\end{tabular} & 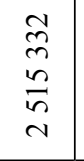 & $\begin{array}{l}0 \\
\& \\
m \\
\sigma \\
-\end{array}$ & $\begin{array}{l}\infty \\
0 \\
\sigma \\
+ \\
\infty \\
\sigma \\
-\end{array}$ & 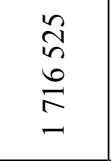 & $\begin{array}{l}\vec{\infty} \\
\infty \\
\infty \\
\infty \\
-\end{array}$ & $\begin{array}{l}\text { ले } \\
\text { aे } \\
\stackrel{+}{+}\end{array}$ & $\begin{array}{l}\text { 号 } \\
\text { L⿱⺊口𧘇口 } \\
\text { m } \\
-1\end{array}$ & $\begin{array}{l}\text { 亏 } \\
\text { in } \\
\text { in }\end{array}$ \\
\hline 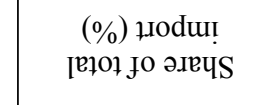 & $\begin{array}{l}8 \\
\dot{8} \\
8\end{array}$ & 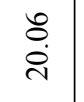 & 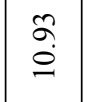 & 节 & $\stackrel{\infty}{i}$ & $\begin{array}{l}\sigma \\
\dot{\sigma} \\
\dot{\gamma}\end{array}$ & $\stackrel{\text { gे }}{n}$ & 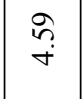 & $\stackrel{\infty}{n}$ & $\stackrel{\dddot{m}}{\dot{m}}$ & পุ \\
\hline 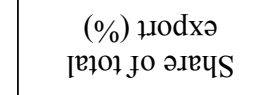 & $\begin{array}{l}8 \\
\dot{8} \\
8\end{array}$ & $\begin{array}{l}\stackrel{\sim}{n} \\
\stackrel{\sim}{*}\end{array}$ & 守 & $\begin{array}{l}n \\
n \\
n\end{array}$ & $\hat{\infty}$ & 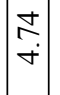 & $\stackrel{\infty}{\underset{\forall}{+}}$ & $\stackrel{\infty}{m}$ & 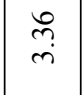 & $\underset{\mathscr{c}}{\stackrel{\leftrightarrow}{i}}$ & $\hat{n}$ \\
\hline 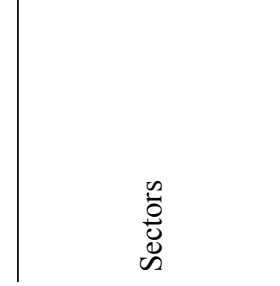 & 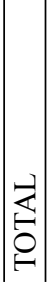 & 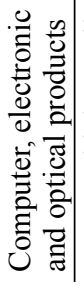 & 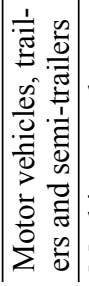 & 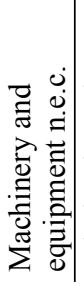 & 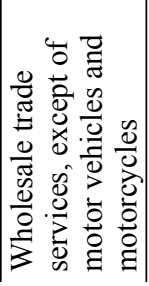 & 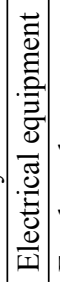 & 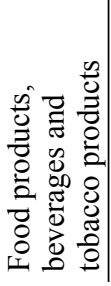 & 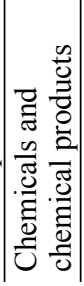 & 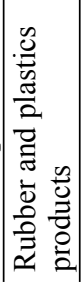 & 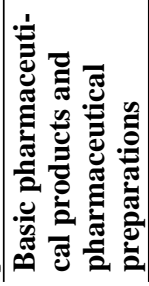 & 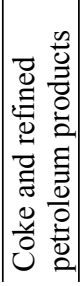 \\
\hline
\end{tabular}




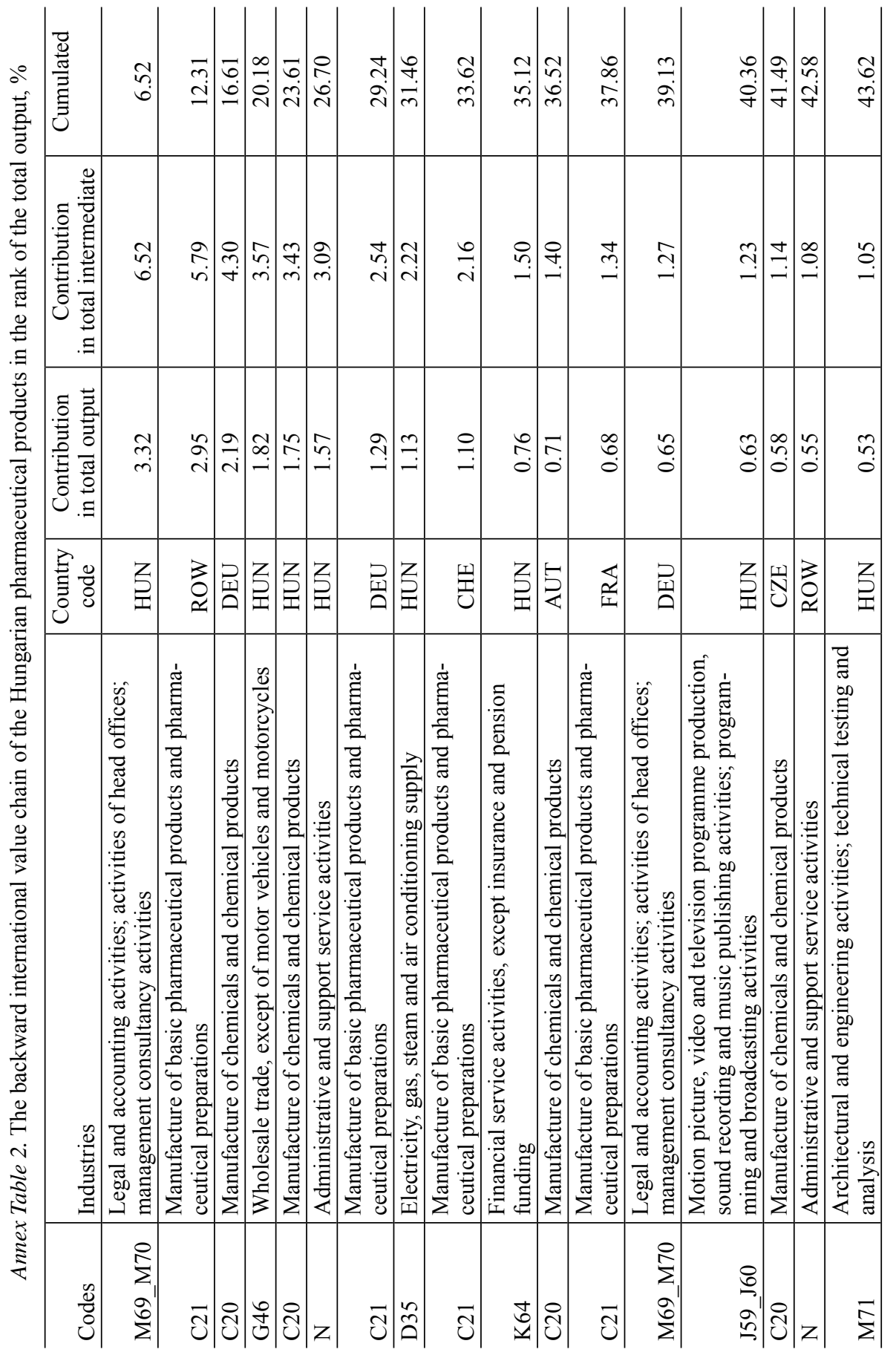




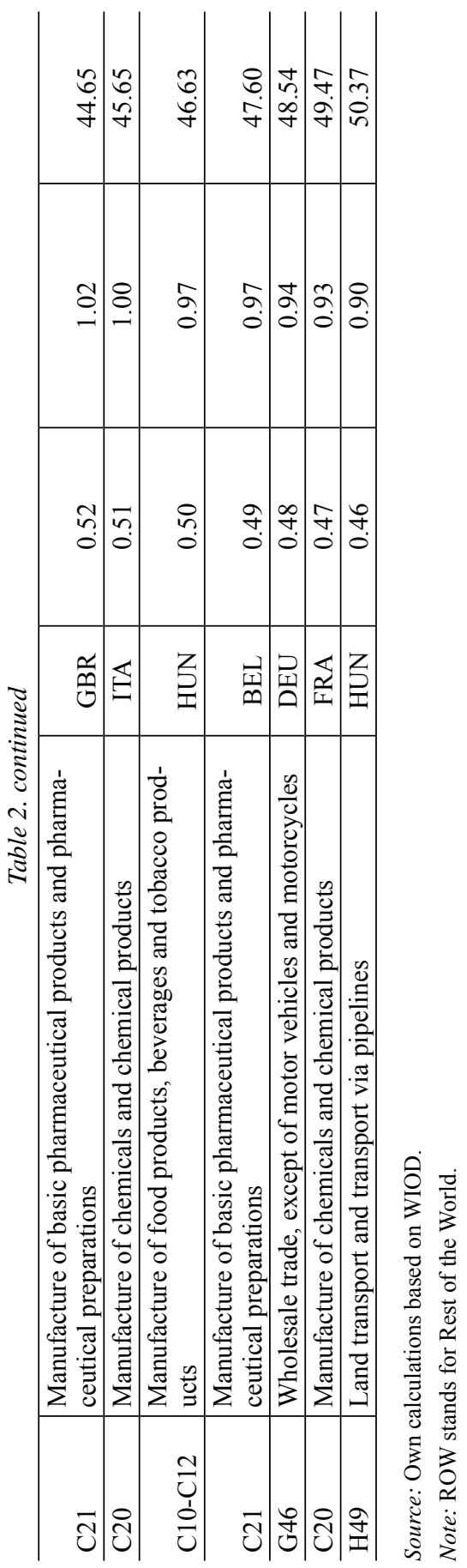


Annex Table 3. The forward international value chain of the Hungarian pharmaceutical products in the rank of the total use, $\%$

\begin{tabular}{l|l|c|c|c}
\hline $\begin{array}{l}\text { Product } \\
\text { code }\end{array}$ & Intermediate consumption or final use & $\begin{array}{c}\text { Country } \\
\text { code }\end{array}$ & Total & Cumulated \\
\hline & Final consumption expenditure by households & ROW & 14.62 & 14.62 \\
\hline & Final consumption expenditure by households & ROU & 7.47 & 22.09 \\
\hline & Final consumption expenditure by households & POL & 4.62 & 26.71 \\
\hline & Gross fixed capital formation & HUN & 4.28 & 30.99 \\
\hline & Final consumption expenditure by government & FRA & 3.66 & 34.65 \\
\hline & Final consumption expenditure by government & ROU & 2.95 & 37.60 \\
\hline & Final consumption expenditure by households & GBR & 2.94 & 40.54 \\
\hline & Final consumption expenditure by households & BGR & 2.92 & 43.46 \\
\hline Q & Final consumption expenditure by government & DEU & 2.44 & 45.90 \\
\hline C21 & Human health and social work activities & ITA & 1.97 & 47.88 \\
\hline & $\begin{array}{l}\text { Manufacture of basic pharmaceutical products } \\
\text { and pharmaceutical preparations }\end{array}$ & ITA & 1.94 & 49.82 \\
\hline & & & & \\
\hline
\end{tabular}

Source: Own calculations based on WIOD.
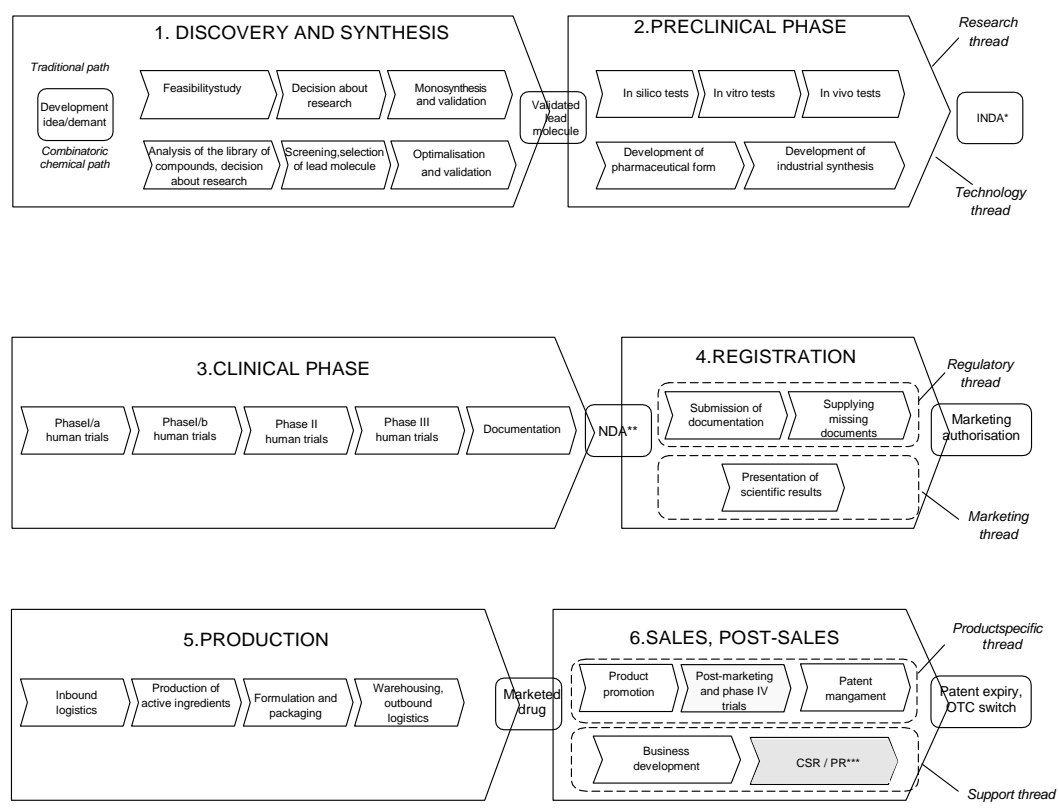

Annex Figure 1. Specific value chain of original pharma firms

\footnotetext{
* INDA - investigational new drug application

** NDA - new drug application

*** CSR / PR - corporate social responsibility / public relations
} 

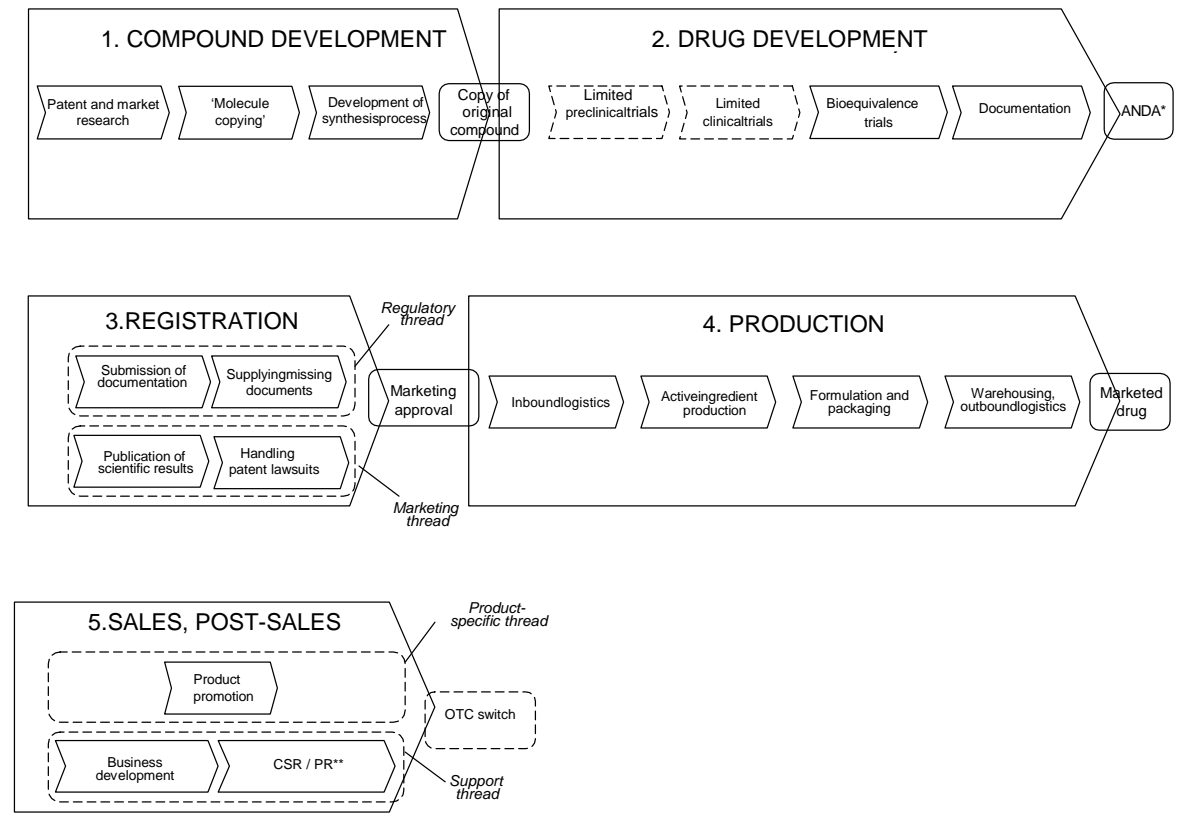

Annex Figure 2. Specific value chain of generic pharma firms

* ANDA - abbreviated new drug application

*** CSR/PR - corporate social responsibility, public relations

Source: Dankó (2011). 